\title{
PENGARUH JOB INVOLVEMENT DAN KEADILAN ORGANISASIONAL TERHADAP KOMITMEN ORGANISASIONAL PADA KARYAWAN PACTO - BALI
}

\author{
Diyah Arum Puspitasari ${ }^{(1)}$ \\ Agoes Ganesha Rahyuda(2) \\ ${ }^{(1),(2)}$ Fakultas Ekonomi dan Bisnis Universitas Udayana, Bali - Indonesia \\ email: diyarum@gmail.com
}

\begin{abstract}
ABSTRAK
Penelitian ini bertujuan untuk mengetahui pengaruh variabel job involvement dan keadilan organisasional terhadap tiga jenis komitmen organisasional, yaitu: komitmen afektif, komitmen kontinuan dan komitmen normatif. Penelitian ini dilakukan di Pacto-Bali, dimana 70 karyawan berpartisipasi sebagai responden penelitian yang dipilih dengan menggunakan teknik sampel jenuh. Pengumpulan data dilakukan melalui pendekatan survei dengan menggunakan kuesioner sebagai instrumennya. Teknik analisis data yang digunakan adalah regresi linier berganda yang diolah menggunakan software SPSS. Hasil penelitian menunjukkan bahwa baik job involvement maupun keadilan organisasional berpengaruh positif terhadap komitmen afektif, komitmen kontinuan serta komitmen normatif. Secara spesifik dapat diketahui bahwa job involvement memberikan pengaruh yang lebih kuat pada komitmen kontinuan dan normatif, sedangkan keadilan organisasional memberikan pengaruh yang lebih kuat pada komitmen afektif. Saran-saran dalam rangka meningkatkan komitmen karyawan Pacto-Bali dipaparkan pada akhir artikel ini.
\end{abstract}

Kata kunci: job involvement, keadilan organisasional, komitmen afektif, komitmen kontinuan, komitmen normatif

ABSTRACT

This study aims to find the effect of job involvement and organizational justice on three types of organizational commitment, which are affective, continuance and normative. This research was conducted in Pacto-Bali, using 70 employees as its respondents. Sampling technique used in this study was saturated sampling technique. Data was collected through interviews and questionnaires. The data analysis technique was multiple linear regression, which was processed using SPSS software.The findings indicate that job involvement has positive influence on each types of organizational commitment, that was affective commitment, continuance commitment and normative commitment. The same finding was found in the relationship between organizational justice and organizational commitment, where the more justice the employees received the more committed the employees to the organization. To improve the organizational commitment of employees, Pacto-Bali should increase employee motivation by inviting employees to involve in the decision making process, and also should improve the networking between the owners and employees in order to help organization to reach its goals.

Keywords: job involvement, organizational justice, organizational commitment

\section{PENDAHULUAN}

Bali sebagai daerah tujuan wisata utama di Indonesia telah mendapatkan perhatian dari pemerintah dalam pengembangan potensi pariwisatanya. Perkembangan pariwisata di Bali dapat dilihat dari segi prasarana yang menjadi pendukung pariwisata itu sendiri. Sebagai sarana penunjang dunia pariwisata, biro perjalanan wisata (tour and travel) bertindak sebagai penghubung antara konsumen (dalam hal ini, wisatawan) dan pihak penyedia jasa, seperti misalnya hotel, restoran, transportasi, dari pihak pengelola objek wisata. Biro perjalanan wisata ini menawarkan jasa yang bertujuan untuk mempermudah wisatawan yang ingin datang dan menikmati keindahan dan pesona Pulau Bali.
Pacto merupakan perusahaan yang bergerak di bidang pelayanan jasa pariwisata. Pacto, yang berlokasi di Bali, diakui sebagai salah satu pelopor pariwisata di Indonesia dan merupakan organisasi paling mapan dalam industri pelayanan pariwisata di Indonesia (Pacto, 2011). Pacto-Bali dapat berkembang dan mempertahankan usahanya tidak terlepas dari dukungan semangat dan perjuangan pemimpin organisasi dan karyawannya dalam mempromosikan dan meningkatkan mutu pelayanan jasa pariwisata, baik ini kepada wisatawan domestik maupun mancanegara. Hermawan (2012) mengatakan bahwa sumber daya manusia (SDM) merupakan faktor yang terpenting dalam suatu perusahaan, sehingga sudah semestinya SDM menjadi perhatian bagi perusahaan dalam rangka 
memenuhi kebutuhan perusahaan akan SDM yang lebih responsif, fleksibel, kompetitif, dan inovatif.

Pacto-Bali membutuhkan karyawan yang berkomitmen dalam rangka mencapai tujuan organisasi yang ditetapkan. Meyer dan Allen (1991) mengidentifikasikan tiga jenis yang berbeda dalam pendefinisian komitmen, yaitu 1) komitmen afektif, yang merupakan suatu ikatan atau hubungan afektif antara karyawan dan organisasi, 2) komitmen kontinuan, yang dipandang sebagai komitmen sebagai suatu biaya yang dirasakan yang berhubungan dengan meninggalkan organisasi, dan 3) komitmen normatif, yaitu komitmen sebagai suatu kewajiban untuk tetap bertahan dalam organisasi. Idealnya, ketiga jenis komitmen inilah yang harus dimiliki oleh para karyawan Pacto-Bali di tempat kerja.

Komitmen menjadi penting karena dampak yang dimilikinya. Azeem (2010) menyatakan bahwa keberhasilan suatu organisasi dalam mengejar kualitas tidak hanya tergantung pada bagaimana organisasi mengembangkan kompetensi karyawannya, namun juga pada bagaimana organisasi meningkatkan komitmen karyawannya, baik komitmen pada pekerjaan maupun pada arahan atasan. Menurut Adiapsari (2012), karyawan yang tidak memiliki komitmen akan menunjukkan kemalasan untuk bekerja keras, sehingga menghambat tujuan organisasi dan memiliki keinginan yang rendah untuk bekerja dan tetap bertahan di lembaga tempatnya bekerja. Hidayah dan Haryani (2013) berpendapat bahwa komitmen tidak dibangun dengan mudah tetapi perlu melalui proses, yang dimulai dari hubungan serta persiapan yang baik, sehingga timbul anggapan positif mengenai kesadaran untuk menerima dan membentuk sebuah komitmen. Namun, ditengah pentingnya Pacto-Bali membutuhkan karyawan yang berkomitmen, Pacto-Bali memiliki beberapa masalah, salah satunya yaitu rendahnya komitmen organisasional yang dimiliki oleh beberapa karyawan. Indikator rendahnya komitmen organisasional karyawan Pacto-Bali dapat dilihat pada Tabel 1.1.

\section{Tabel 1. Indikator Rendahnya Komitmen Organisasional pada Karyawan Pacto - Bali}

\begin{tabular}{cl}
\hline Indikator Komitmen Organisasional & \multicolumn{1}{c}{ Fakta Komitmen Organisasional Rendah } \\
\hline Komitmen Afektif & $\begin{array}{l}\text { Karyawan masih kurang terbuka terhadap rekan } \\
\text { kerja di area perusahaan dan masih menganggap } \\
\text { masalah perusahaan kurang penting bagi dirinya }\end{array}$ \\
\hline Komitmen Kontinuan & $\begin{array}{l}\text { Karyawan masih merasa bahwa perusahaan lain } \\
\text { dibidang yang sama memberikan keuntungan yang } \\
\text { lebih besar }\end{array}$ \\
\hline Komitmen Normatif & $\begin{array}{l}\text { Sebagian kecil dari karyawan memilih untuk keluar } \\
\text { atau pindah ke perusahaan lain. }\end{array}$ \\
\hline
\end{tabular}

Sumber : Hasil Wawancara, 2016

Beberapa penelitian menunjukkan bahwa job involvement merupakan variabel yang memiliki pengaruh kuat terhadap komitmen organisasional. Chungtai (2008) mengatakan bahwa job involvement atau keterlibatan kerja akan meningkatkan komitmen organisasional diantara karyawan oleh karena karyawan yang berkomitmen akan mengerahkan segala usaha dan tenaganya dalam bekerja dalam rangka membantu organisasi mencapai tujuannya. Job involvement didefinisikan sebagai derajat dimana orang dikenal dari pekerjaannya, berpartisipasi aktif didalamnya, dan menganggap prestasinya penting untuk harga diri (Robbins, 2003:91).

Keadilan organisasi merupakan faktor lainnya yang mampu mempengaruhi komitmen organisasional.
Teori yang mendasari hubungan antara keadilan organisasional dengan komitmen organisasional yaitu teori keadilan (equity theory) (Gibson et al., 1995:150) yang mengatakan bahwa karyawan akan membandingkan imbalan yang mereka peroleh dengan imbalan karyawan lainnya dalam situasi kerja yang sama. Keadilan organisasi sendiri didefinisikan sebagai suatu konsep keseimbangan, baik prosedural, informasional maupun interaksional, dalam memperlakukan karyawan di suatu organisasi dalam rangka meningkatkan komitmen kerja karyawan terhadap organisasi (Sutrisna dan Rahyuda, 2014). Tujuan penelitian ini yaitu: 1) Untuk mengetahui pengaruh job involvement terhadap komitmen afektif pada karyawan Pacto-Bali, 2) Untuk mengetahui pengaruh job involvement 
terhadap komitmen kontinuan pada karyawan Pacto-Bali, 3) Untuk mengetahui pengaruh job involvement terhadap komitmen normatif pada karyawan Pacto-Bali, 4) Untuk mengetahui pengaruh keadilan organisasional terhadap komitmen afektif karyawan pada Pacto-Bali, 5) Untuk mengetahui pengaruh keadilan organisasional terhadap komitmen kontinuan karyawan pada Pacto-Bali dan 6) Untuk mengetahui pengaruh keadilan organisasional terhadap komitmen normatif karyawan pada Pacto-Bali.

Komitmen organisasional didefinisikan sebagai pendekatan psikologis antara karyawan dan organisasi yang berimplikasi terhadap keputusan untuk bertahan atau keluar dari organisasi (Meyer dan Allen, 1991). Adekola (2012) mendefinisikan bahwa komitmen organisasi merupakan sikap karyawan atau kekuatan organisasi dalam mengikat karyawan agar tetap berada di dalam organisasi. Adiapsari (2012) mengatakan karyawan yang memiliki komitmen akan menunjukkan kemauan bekerja keras untuk mencapai tujuan organisasi dan memiliki keinginan yang kuat untuk bekerja dan tetap bertahan di lembaga tempatnya bekerja. Meyer dan Allen (1991) menjelaskan bahwa terdapat tiga dimensi komitmen organisasional, yaitu: 1) Komitmen afektif, 2) Komitmen kontinuan, 3) Komitmen normatif.

Job involvement merupakan salah satu faktor yang mampu mempengaruhi komitmen. Menurut Faslah (2010) job involvement atau yang sering disebut dengan keterlibatan kerja adalah derajat dimana seseorang mengidentifikasi secara psikologis terhadap pekerjaannya, atau pentingnya pekerjaan tersebut terhadap keseluruhan citra diri. Robbins dan Judge (2008:100) mengatakan bahwa job involvement diartikan sebagai suatu ukuran sampai dimana individu secara psikologis memihak pekerjaan mereka dan menganggap penting tingkat kinerja yang dicapai sebagai penghargaan diri. Govender (2010) mengatakan bahwa ada empat indikator untuk mengukur job involvement: 1) Respon untuk bekerja, 2) Perilaku melibatkan diri dalam pekerjaan, 3) Rasa bertanggung jawab terhadap pekerjaan, dan 4) Perasaan tentang pekerjaan yang belum terselesaikan dan absensi.

Beberapa penelitian (Chin, 2012; Chungtai, 2008; Khan, 2011; Logahan, 2014; Uygur, 2009) mengatakan bahwa job involvement memiliki pengaruh positif terhadap komitmen organisasional. Hal tersebut juga dapat diartikan bahwa job involvement juga berpengaruh terhadap ketiga jenis komitmen organisasional yaitu: komitmen afektif, komitmen kontinuan dan komitmen normatif. Semakin tinggi tingkat job involvement karyawan, maka semakin meningkat komitmen organisasional yang dimiliki karyawan. Berdasarkan teori dan hasil penelitian terdahulu, maka hipotesis yang diajukan dalam penelitian ini adalah sebagai berikut:

$\mathrm{H}_{1}$ : Job involvement berpengaruh positif terhadap komitmen afektif

$\mathrm{H}_{2}$ : Job involvement berpengaruh positif terhadap komitmen kontinuan

$\mathrm{H}_{3}$ : Job involvement berpengaruh positif terhadap komitmen normatif

Keadilan organisasi adalah suatu konsep keseimbangan yang diharapkan mampu diterapkan oleh organisasi dalam memperlakukan karyawan dengan tujuan memicu tumbuhnya rasa berkomitmen dalam diri karyawan (Sutrisna dan Rahyuda, 2014). Secara umum keadilan digunakan untuk menjelaskan pandangan dan perasaan pekerja tentang sikap mereka sendiri dalam organisasi, dan hal itu dihubungkan dengan pemahaman mereka dalam menyatukan persepsi secara subyektif yang dihasilkan dari hasil keputusan yang diambil organisasi, prosedur dan proses yang digunakan untuk menuju pada keputusan-keputusan ini serta implementasinya (Nugraheni dan Wijayanti, 2009). Keadilan organisasi terdiri dari beberapa unsur utama. Menurut Bakshi et al. (2009) menyebutkan bahwa keadilan organisasi terbentuk dari tiga unsur, yaitu: 1) Keadilan distributif; 2) Keadilan prosedural; dan 3) Keadilan interaksional.

Teori keadilan (equity theory) (Gibson et al. (1995:150) mengatakan bahwa inti dari teori keadilan ialah karyawan membandingkan usaha mereka terhadap imbalan dengan imbalan karyawan lainnya dalam situasi kerja yang sama. Teori keadilan (equity theory) merupakan persepsi karyawan yang menilai suatu organisasi adil atau tidak adil melalui perbandingan antara kontribusi karyawan kepada organisasi (misalnya, pengetahuan dan usaha) dan hasil yang diberikan oleh organisasi seperti pembayaran atau gaji dan pengakuan (Ibrahim dan Perez, 2014). Penelitian yang dilakukan oleh Dehkordi et al. (2013), Kristanto (2015), Bakhshi (2009) dan Karim dan Rehman (2012) menemukan fakta bahwa keadilan organisasional berpengaruh positif terhadap komitmen organisasional. Hal tersebut juga dapat diartikan bahwa komitmen organisasional juga berpengaruh terhadap ketiga jenis komitmen organisasional yaitu: komitmen afektif, komitmen kontinuan, dan komitmen normatif. Rendahnya tingkat keadilan di dalam organisasi akan menciptakan komitmen organisasional yang rendah. 
Berdasarkan teori dan hasil penelitian terdahulu, maka hipotesis yang diajukan dalam penelitian ini adalah sebagai berikut:

$\mathrm{H}_{4}$ : Keadilan organisasional berpengaruh positif terhadap komitmen afektif

$\mathrm{H}_{5}$ : Keadilan organisasional berpengaruh positif terhadap komitmen kontinuan
$\mathrm{H}_{6}$ : Keadilan organisasional berpengaruh positif terhadap komitmen normatif

Berdasarkan rumusan hipotesis dan studi empiris, maka dapat dibuat kerangka konseptual sebagai berikut:

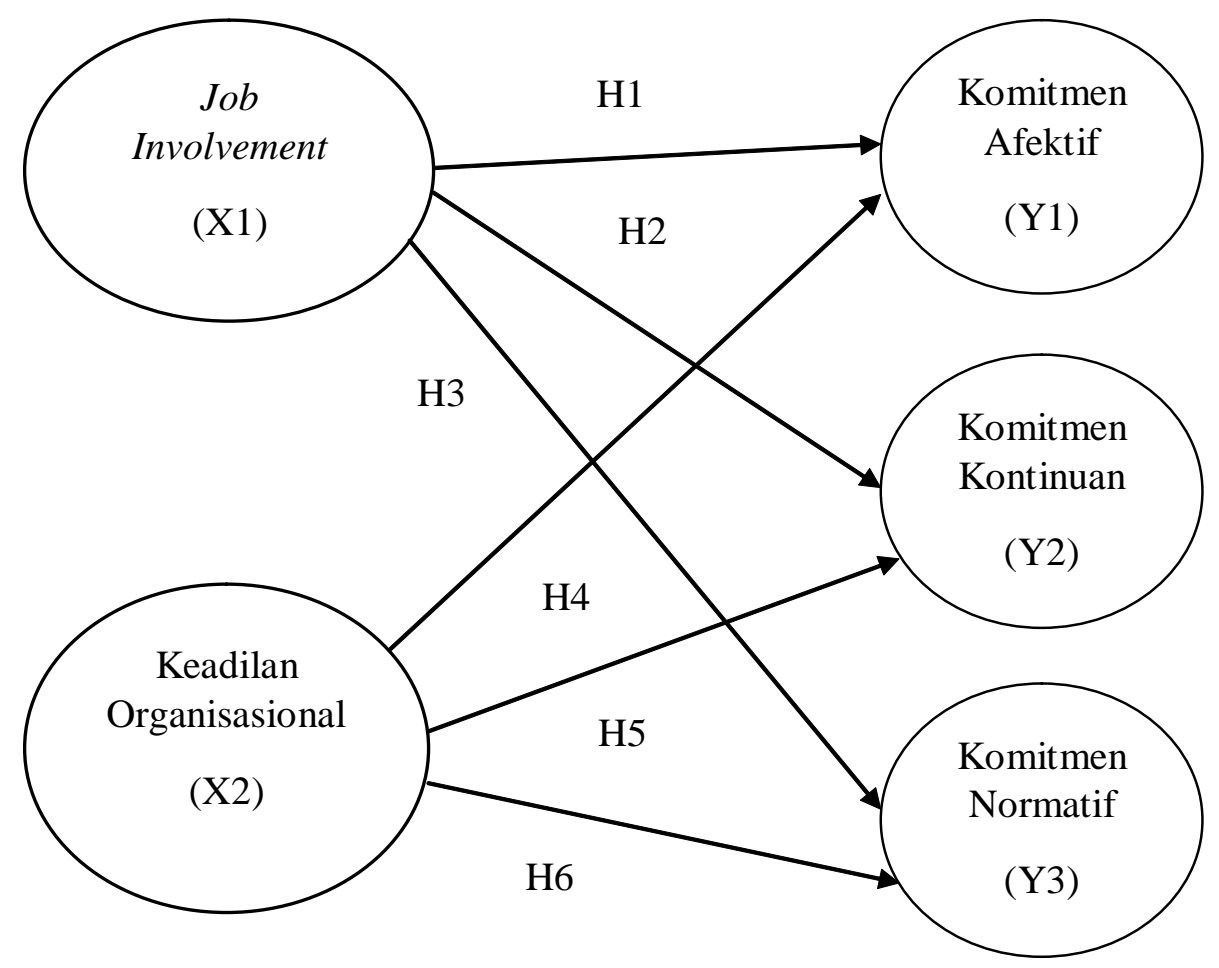

Gambar 1. Kerangka Konseptual

Sumber: kajian konseptual dan empiris

\section{METODE}

Metode penelitian ini adalah asosiatif yang menggunakan 2 (tiga) variabel bebas dan 3 (tiga) variabel terikat. Variabel yang digunakan dalam penelitian ini adalah tiga variabel terikat, yang terdiri dari komitmen afektif, komitmen kontinuan dan komitmen normative, serta dua variabel bebas yaitu job involvement dan keadilan organisasional. Jumlah sampel yang diambil adalah sebanyak 70 (tujuh puluh) orang. Sampel yang diambil berdasarkan teknik sampling jenuh, dimana seluruh populasi menjadi sampel penelitian. Metode pengumpulan data yang digunakan pada penelitian ini yaitu dengan cara wawancara dan kuesioner.

Model analisis yang dipergunakan untuk menyelesaikan permasalahan dalam penelitian ini adalah regresi linier berganda. Analisis ini digunakan untuk mengetahui ketergantungan suatu variabel terikat dengan satu atau lebih variabel bebas.Dimana dalam penelitian ini variabel terikat adalah komitmen organisasi, sedangkan variable bebas adalah job involvement dan Keadilan Organisasional (komitmen afektif, komitmen kontinuan dan komitmen normatif). Model regresi linear berganda yang dimaksud dirumuskan sebagai berikut :

$Y_{1}=B o+B_{1} X_{1}+B_{2} X_{2}+e$
$Y_{2}=B o+B_{1} X_{1}+B_{2} X_{2}+e . \ldots$
$Y_{3}=B o+B_{1} X_{1}+B_{2} X_{2}+e .$.

Dimana:

$\mathrm{Y}_{1}=$ Komitmen afektif

$\mathrm{Y}_{2}=$ Komitmen kontinuan

$\mathrm{Y}_{3}=$ Komitmen normatif

$\mathrm{X}_{1}=$ Job involvement

$\mathrm{X}_{2}=$ Keadilan Organisasional

$\mathrm{Bo}=$ Intersep $\mathrm{Y}$

$\mathrm{B}_{1}=$ Koefesien Variabel $\mathrm{X}_{1}$

$\mathrm{B}_{2}=$ Koefesien Variabel $\mathrm{X}_{2}$

$\varepsilon=$ Error of term (Variabel yang tidak terungkap) 


\section{HASIL DAN PEMBAHASAN}

Tabel 2 menjelaskan responden yang diteliti berjumlah 70 orang yang digunakan sebagai sampel dalam penelitian ini. Secara spesifik, sesponden penelitian digambarkan dengan menyajikan karakteristiknya berdasarkan variabel demografi yaitu umur, jenis kelamin, pendidikan, masa kerja dan unit kerja.

Tabel 2. Karakteristik Responden Penelitian

\begin{tabular}{|c|c|c|c|c|}
\hline No & Kriteria & Klasifikasi & $\begin{array}{l}\text { Jumlah } \\
\text { (Orang) }\end{array}$ & Presentase $(\%)$ \\
\hline \multirow{4}{*}{1} & \multirow{4}{*}{ Umur } & 21-30 tahun & 28 & 40 \\
\hline & & 31-40 tahun & 30 & 43 \\
\hline & & 41-50 tahun & 11 & 16 \\
\hline & & 51-60 tahun & 1 & 1 \\
\hline & Jumlah & & 70 & 100 \\
\hline \multirow{2}{*}{2} & \multirow{2}{*}{ Jenis Kelamin } & Laki-laki & 41 & 59 \\
\hline & & Perempuan & 29 & 41 \\
\hline & Jumlah & & 70 & 100 \\
\hline \multirow{5}{*}{3} & \multirow{5}{*}{ Pendidikan } & SMA/SMK & 20 & 29 \\
\hline & & D1 & 1 & 1 \\
\hline & & D2 & 2 & 3 \\
\hline & & D3 & 13 & 19 \\
\hline & & $\mathrm{S} 1$ & 34 & 49 \\
\hline & Jumlah & & 70 & 100 \\
\hline \multirow{5}{*}{4} & \multirow{5}{*}{ Masa Kerja } & 1-5 tahun & 39 & 56 \\
\hline & & 6-10 tahun & 22 & 31 \\
\hline & & 11-15 tahun & 3 & 4 \\
\hline & & 16-20 tahun & 2 & 3 \\
\hline & & 21-30 tahun & 4 & 6 \\
\hline & Jumlah & & 70 & 100 \\
\hline \multirow{8}{*}{5} & \multirow{7}{*}{ Jabatan/Unit Kerja } & Operational & 11 & 16 \\
\hline & & Transport & 15 & 21 \\
\hline & & Airport & 10 & 14 \\
\hline & & Reservation & 10 & 14 \\
\hline & & Marketing & 11 & 16 \\
\hline & & Accounting & 7 & 10 \\
\hline & & $H R D$ & 6 & 9 \\
\hline & Jumlah & & 70 & 100 \\
\hline
\end{tabular}

Sumber: Data statistik diolah, 2015

Hasil uji validitas menunjukkan bahwa seluruh variabel memiliki nilai koefisien korelasi dengan skor total seluruh butir pernyataan lebih besar dari 0,30. Hal ini menunjukkan bahwa butir-butir pernyataan dalam instrumen penelitian tersebut valid, dalam artian instrumen penelitian layak untuk diuji.

Hasil uji reliabilitas yang disajikan dalam tabel 4 menunjukkan bahwa seluruh instrumen penelitian memiliki koefisien Cronbach's Alpha lebih dari 0,60.
Semua instrumen reliabel sehingga dapat digunakan untuk melakukan penelitian, dalam artian bahwa instrumen penelitian tersebut apabila digunakan beberapa kali untuk mengukur objek yang sama akan menghasilkan data yang sama.

\section{Deskripsi Variabel Penelitian}

Suharso (2010:21) menyatakan bahwa untuk mendeskripsikan mengenai hasil instrumen yang 
diperoleh, maka jawaban responden dikelompokkan dengan rentang kriteria sebagai berikut:

$$
\begin{array}{ll}
1,00-1,80 & =\text { sangat rendah (sangat tidak baik) } \\
1,81-2,61 & =\text { rendah (tidak baik) }
\end{array}
$$

$2,62-3,42=$ netral (cukup baik)

$3,43-4,23=$ tinggi (baik)

$4,24-5,00=$ sangat tinggi (sangat baik)

\begin{tabular}{|c|c|c|c|c|c|c|c|c|}
\hline No & Pernyataan & STS & TS & $\mathrm{N}$ & S & SS & $\begin{array}{c}\text { Rata - } \\
\text { Rata }\end{array}$ & Kriteria \\
\hline 1 & $\begin{array}{l}\text { Respon yang saya berikan } \\
\text { terhadap suatu pekerjaan sesuai } \\
\text { dengan apa yang saya } \\
\text { harapkan (ekspektasi) (X1.1) }\end{array}$ & - & 6 & 14 & 46 & 4 & 3,69 & Tinggi \\
\hline 2 & $\begin{array}{l}\text { Saya terlibat langsung dalam } \\
\text { setiap pekerjaan yang telah } \\
\text { ditugaskan kepada saya (X1.2) }\end{array}$ & - & - & 13 & 49 & 8 & 3,93 & Tinggi \\
\hline 3 & $\begin{array}{l}\text { Saya berprinsip bahwa semua } \\
\text { pekerjaan yang dilimpahkan } \\
\text { harus diselesaikan sesuai target } \\
\text { pekerjaan itu sendiri (X1.3) }\end{array}$ & - & 2 & 14 & 47 & 7 & 3,84 & Tinggi \\
\hline 4 & $\begin{array}{l}\text { Saya merasa tidak tenang } \\
\text { apabila pekerjaan belum } \\
\text { terselesaikan (X1.4) }\end{array}$ & - & 2 & 21 & 40 & 7 & 3,74 & Tinggi \\
\hline & Rata-rata keseluruha & ariab & epu & 1 & & & 3,80 & Tinggi \\
\hline
\end{tabular}

Tabel 3. Deskripsi Persepsi Responden Terhadap Variabel Job Involvement

Sumber: Data statistik diolah, 2016

Berdasarkan Tabel 3, rata-rata jawaban tertinggi ditunjukkan pada pernyataan saya terlibat langsung dalam setiap pekerjaan yang telah ditugaskan kepada saya dengan nilai 3,93. Sebanyak 8 orang responden menjawab sangat setuju, 49 orang responden menjawab setuju dan 13 orang responden menjawab netral. Hal tersebut berarti bahwa karyawan merasa senang jika ia memahami dan ikut berperan penuh dengan pekerjaannya sendiri. Skor rata-rata jawaban terendah ditunjukkan pada pernyataan respon yang saya berikan terhadap suatu pekerjaan sesuai dengan apa yang saya harapkan (ekspektasi) dengan nilai 3,69. Sebanyak 4 orang responden menjawab sangat setuju, 46 orang responden menjawab setuju, 14 orang responden menjawab netral dan 6 orang responden menjawab tidak setuju. Hasil tersebut menunjukkan bahwa pekerjaan yang diharapkan oleh karyawan tidak sesuai dengan kenyataan yang ada di dalam perusahaan sehingga karyawan memberikan respon yang tidak bagus bagi jalannya perusahaan.

Rata-rata keseluruhan persepsi responden mengenai variabel job involvement adalah sebesar 3,80 yang berada di rentang nilai $3,43-4,23$ yang berarti bahwa job involvement yang dimiliki karyawan di Pacto - Bali dalam kondisi baik.

Berdasarkan Tabel 4, rata-rata jawaban tertinggi ditunjukkan pada pernyataan perusahaan menghormati hak - hak saya sebagai karyawan dengan nilai 3,77. Sebanyak 9 orang responden menjawab sangat setuju, 36 orang responden menjawab setuju dan 25 orang responden menjawab netral. Hal tersebut berarti bahwa karyawan merasa senang dalam bekerja karena perusahaan memikirkan tentang kesejahteraan karyawan yang berupa hak yang didapat sebagai karyawan dalam perusahaan. Skor rata-rata jawaban terendah ditunjukkan pada 2 pernyataan berikut dikarenakan memperoleh hasil yang sama yaitu : Perusahaan memberikan kepercayaan penuh pada setiap tugas yang saya lakukan dengan nilai rata-rata 3,46. Sebanyak 3 orang responden menjawab sangat setuju, 31 orang responden menjawab setuju, 31 orang responden menjawab netral dan 5 orang responden menjawab tidak setuju. Berarti bahwa perusahaan belum sepenuhnya percaya terhadap kinerja dari karyawan dalam menyelesaikan pekerjaan yang telah ditentukan.

Pernyataan selanjutnya yang menghasilkan skor rata - rata terendah adalah penyataan prosedur kerja yang dilaksanakan sudah diterapkan secara adil dengan nilai rata-rata 3,46 . Sebanyak 4 orang responden menjawab sangat setuju, 31 orang responden menjawab setuju, 28 orang responden menjawab netral dan 7 orang responden menjawab tidak setuju. Berarti tahapan kerja masih belum 
Tabel 4. Deskripsi Persepsi Responden Terhadap Variabel Keadilan Organisasional

\begin{tabular}{|c|c|c|c|c|c|c|c|c|}
\hline No & Pernyataan & STS & TS & $\mathrm{N}$ & $\mathrm{S}$ & SS & $\begin{array}{c}\text { Rata - } \\
\text { Rata }\end{array}$ & Kriteria \\
\hline 1 & $\begin{array}{l}\text { Perusahaan telah memberikan } \\
\text { imbalan yang adil pada setiap } \\
\text { karyawan (X2.1) }\end{array}$ & - & 2 & 34 & 33 & 1 & 3,47 & Tinggi \\
\hline 2 & $\begin{array}{l}\text { Perusahaan memberikan } \\
\text { kepercayaan penuh pada setiap } \\
\text { tugas yang saya lakukan (X2.2) }\end{array}$ & - & 5 & 31 & 31 & 3 & 3,46 & Tinggi \\
\hline 3 & $\begin{array}{l}\text { Prosedur kerja yang } \\
\text { dilaksanakan sudah diterapkan } \\
\text { secara adil (X2.3) }\end{array}$ & - & 7 & 28 & 31 & 4 & 3,46 & Tinggi \\
\hline 4 & $\begin{array}{l}\text { Perusahaan memberikan } \\
\text { kesempatan yang sama bagi } \\
\text { karyawan untuk ikut dalam } \\
\text { pengambilan keputusan (X2.4) }\end{array}$ & - & 11 & 18 & 36 & 5 & 3,50 & Tinggi \\
\hline 5 & $\begin{array}{l}\text { Perusahaan menunjukkan } \\
\text { kepedulian terhadap } \\
\text { karyawannya (X2.5) }\end{array}$ & - & - & 26 & 35 & 9 & 3,76 & Tinggi \\
\hline 6 & $\begin{array}{l}\text { Perusahaan menghormati hak - } \\
\text { hak saya sebagai karyawan } \\
(\mathrm{X} 2.6)\end{array}$ & - & - & 25 & 36 & 9 & 3,77 & Tinggi \\
\hline \multicolumn{7}{|c|}{ Rata-rata keseluruhan variabel keadilan organisasional } & 3,57 & Tinggi \\
\hline
\end{tabular}

Sumber: Data statistik diolah, 2016

diterapkan secara adil yang dapat menimbulkan kesenjangan dalam bekerja antara karyawan satu dengan yang lainnya. Rata-rata keseluruhan persepsi responden mengenai variabel keadilan organisasional adalah sebesar 3,57 yang berada di rentang nilai 3,43-4,23 yang berarti bahwa keadilan organisasional yang dirasakan karyawan di Pacto Bali dalam kondisi baik.

Tabel 5. Deskripsi Persepsi Responden Terhadap Variabel Komitmen Afektif

\begin{tabular}{|c|c|c|c|c|c|c|c|c|}
\hline No & Pernyataan & STS & TS & $\mathrm{N}$ & S & SS & $\begin{array}{c}\text { Rata - } \\
\text { Rata }\end{array}$ & Kriteria \\
\hline 1 & $\begin{array}{l}\text { Permasalahan dari perusahaan } \\
\text { menjadi bagian dari } \\
\text { permasalahan saya (Y1.1) }\end{array}$ & - & 11 & 18 & 39 & 2 & 3,46 & Tinggi \\
\hline 2 & $\begin{array}{l}\text { Saya menghabiskan } \\
\text { keseluruhan karir saya di } \\
\text { perusahaan dengan bahagia } \\
\text { (Y1.2) }\end{array}$ & 1 & 8 & 30 & 28 & 3 & 3,34 & Netral \\
\hline 3 & $\begin{array}{l}\text { Perusahaan sudah menjadi } \\
\text { bagian dari keluarga saya } \\
\text { (Y1.3) }\end{array}$ & - & - & 21 & 43 & 6 & 3,79 & Tinggi \\
\hline \multicolumn{7}{|c|}{ Rata-rata keseluruhan variabel komitmen afektif } & $\mathbf{3 , 5 2}$ & Tinggi \\
\hline
\end{tabular}

Sumber: Data statistik diolah, 2016 
135 Diyah Arum Puspitasari, Pengaruh Job Involvement dan Keadilan ...

Berdasarkan Tabel 5 rata-rata jawaban tertinggi ditunjukkan pada pernyataan perusahaan sudah menjadi bagian dari keluarga saya dengan nilai rata-rata 3,79. Karyawan sudah menganggap bahwa perusahaan merupakan bagian dari keluarganya yang memiliki tingkat kepentingan yang utama dalam kehidupan karyawan. Sebanyak 6 orang responden menjawab sangat setuju, 43 orang responden menjawab setuju, sedangakan 21 orang responden menjawab netral. Skor rata-rata terendah ditunjukkan pada saya menghabiskan keseluruhan karir saya di perusahaan dengan bahagia dengan nilai 3,34. Sebanyak 3 orang responden menjawab sangat setuju, 28 orang responden menjawab setuju, 30 orang responden menjawab netral, sedangkan 8 orang responden menjawab tidak setuju dan 1 orang responden menjawab sangat tidak setuju. Karyawan akan lebih cepat untuk keluar dari perusahaan karena mereka berasumsi bahwa tidak ada rasa bahagia dalam menjalani pekerjaan di perusahaan.

Rata-rata keseluruhan persepsi responden mengenai variabel komitmen afektif adalah sebesar 3,52 yang berada di rentang nilai $3,43-4,23$ yang berarti bahwa komitmen afektif yang dimiliki karyawan di Pacto - Bali dalam kondisi baik.

Tabel 6. Deskripsi Persepsi Responden Terhadap Variabel Komitmen Kontinuan

\begin{tabular}{lllllllll}
\hline No & \multicolumn{1}{c}{ Pernyataan } & STS & TS & N & S & SS & $\begin{array}{c}\text { Rata } \\
\text { Rata }\end{array}$ & Kriteria \\
\hline 1 & $\begin{array}{l}\text { Saya bekerja di perusahaan } \\
\text { untuk memenuhi kebutuhan } \\
\text { finansial (Y2.1) }\end{array}$ & - & - & 7 & 56 & 7 & 4,00 & Tinggi \\
\hline 2 & $\begin{array}{l}\text { Salah satu alasan saya tetap } \\
\text { bekerja adalah beberapa } \\
\text { perusahaan lainnya tidak } \\
\text { memberikan benefit setara } \\
\text { dengan di perusahaan ini } \\
\text { (Y2.2) }\end{array}$ & - & 13 & 20 & 34 & 3 & 3,39 & Netral \\
\hline 3 & $\begin{array}{l}\text { Saya memiliki sedikit pilihan } \\
\text { untuk keluar dari perusahaan } \\
\text { ini (Y2.3) }\end{array}$ & - & 9 & 31 & 29 & 1 & 3,31 & Netral \\
\hline \multicolumn{1}{c}{ Rata-rata keseluruhan variabel komitmen kontinuan } & & & & & & & & \\
\hline
\end{tabular}

Sumber: Data statistik diolah, 2016

Berdasarkan Tabel 6, rata-rata jawaban tertinggi ditunjukkan pada pernyataan saya bekerja di perusahaan untuk memenuhi kebutuhan finansial dengan nilai rata-rata 4,00 . Sebanyak 7 orang responden menjawab sangat setuju, 56 orang responden menjawab setuju dan 7 orang responden menjawab netral. Karyawan bekerja pada perusahaan mempunyai tujuan untuk memenuhi kehidupan karyawan itu sendiri, terutama dalam kebutuhan finansial. Skor rata-rata terendah ditunjukkan pada pernyataan saya memiliki sedikit pilihan untuk keluar dari perusahaan ini dengan nilai 3,31 . Sebanyak 1 orang responden menjawab sangat setuju, 29 orang responden menjawab setuju, 31 orang responden menjawab netral dan 9 orang responden menjawab tidak setuju. Karyawan memiliki keraguan untuk bertahan dan telah memikirkan pilihan untuk keluar dari perusahaan. Rata-rata keseluruhan persepsi responden mengenai variabel komitmen kontinuan adalah sebesar 3,57 yang berada di rentang nilai 3,43 - 4,23 yang berarti bahwa komitmen kontinuan yang dimiliki karyawan di Pacto - Bali dalam kondisi baik.

Berdasarkan Tabel 7, rata-rata jawaban tertinggi ditunjukkan pada pernyataan saya loyal dalam bekerja di perusahaan ini karena perusahaan ini telah berkontribusi besar bagi kehidupan saya dengan nilai rata-rata 3,74. Sebanyak 6 orang responden menjawab sangat setuju, 45 orang responden menjawab setuju, sedangkan 14 orang responden menjawab netral dan 5 orang responden menjawab tidak setuju. Karyawan merasa senang dan akan setia dalam bekerja di perusahaan karena perusahaan telah memberikan timbal balik yang besar bagi kehidupan karyawan.

Skor rata-rata terendah ditunjukkan pada pernyataan saya komit dalam bekerja karena asas kekeluargaan yang dimiliki oleh setiap karyawan dengan nilai 3,51. Sebanyak 2 orang responden menjawab sangat setuju, 41 orang responden 
Tabel 7. Deskripsi Persepsi Responden Terhadap Variabel Komitmen Normatif

\begin{tabular}{lllllllll}
\hline No & \multicolumn{1}{c}{ Pernyataan } & STS & TS & N & S & SS & $\begin{array}{c}\text { Rata }- \\
\text { Rata }\end{array}$ & Kriteria \\
\hline 1 & $\begin{array}{l}\text { Saya loyal dalam bekerja di } \\
\text { perusahaan ini karena } \\
\text { perusahaan ini telah } \\
\text { berkontribusi besar bagi } \\
\text { kehidupan saya (Y3.1) }\end{array}$ & - & 5 & 14 & 45 & 6 & 3,74 & Tinggi \\
\hline 2 & $\begin{array}{l}\text { Berpindah dari satu organisasi } \\
\text { ke organisasi lain tampak } \\
\text { tidak etis untuk saya (Y3.2) }\end{array}$ & - & 3 & 18 & 46 & 3 & 3,70 & Tinggi \\
\hline 3 & $\begin{array}{l}\text { Saya komit dalam bekerja } \\
\text { karena asas kekeluargaan } \\
\text { yang dimiliki oleh setiap } \\
\text { karyawan (Y3.3) }\end{array}$ & - & 9 & 18 & 41 & 2 & 3,51 & Tinggi \\
\hline \multicolumn{1}{c}{ Rata-rata keseluruhan variabel komitmen kontinuan } & & & & & & & & \\
\hline
\end{tabular}

Sumber: Data statistik diolah, 2016

menjawab setuju, 18 orang responden menjawab netral dan 9 orang responden menjawab tidak setuju. Karyawan merasa tidak tenang dalam bekerja karena lingkungan internal perusahaan tidak memiliki sifat kekeluargaan antara karyawan satu dengan yang lainnya. Rata-rata keseluruhan persepsi responden mengenai variabel komitmen normatif adalah sebesar 3,65 yang berada di rentang nilai 3,43 - 4,23 yang berarti bahwa komitmen normatif yang dimiliki karyawan di Pacto - Bali dalam kondisi baik.

\section{Uji Asumsi Klasik}

Hasil uji asumsi klasik yang dilakukan dalam penelitian ini adalah uji normalitas, uji multikoliniearitas dan uji heteroskedastisitas. Hasil dari uji asumsi klasik yang diolah dengan bantuan software SPSS 18.0 disajikan sebagai berikut:

Uji normalitas bertujuan untuk mengetahui apakah residual dari model regresi yang dibuat berdistribusi normal atau tidak.

Berdasarkan Tabel 8,. dapat dilihat bahwa nilai Kolmogorov Sminarnov (K-S) sebesar 1,199, sedangkan nilai Asymp. Sig. (2-tailed) sebesar 0,113 . Hasil tersebut mengindikasikan bahwa model persamaan regresi tersebut berdistribusi normal karena nilai Asymp. Sig. (2-tailed) 0,113lebih besar dari nilai alpha 0,05 .

Tabel 8. Hasil Uji Normalitas Struktur 1

\begin{tabular}{cc}
\hline & $\begin{array}{c}\text { Unstandardized } \\
\text { Residual }\end{array}$ \\
\hline $\mathrm{N}$ & 70 \\
Kolmogorov-Smirnov $Z$ & 1,199 \\
Asymp.Sig.(2-tailed) & 0,113 \\
\hline Sumber.
\end{tabular}

Sumber: Data statistik diolah, 2016
Berdasarkan Tabel 8,. dapat dilihat bahwa nilai Kolmogorov Sminarnov (K-S) sebesar 1,199, sedangkan nilai Asymp. Sig. (2-tailed) sebesar 0,113 . Hasil tersebut mengindikasikan bahwa model persamaan regresi tersebut berdistribusi normal karena nilai Asymp. Sig. (2-tailed) 0,113lebih besar dari nilai alpha 0,05 .

Tabel 9. Hasil Uji Normalitas Struktur 2

\begin{tabular}{cc}
\hline & $\begin{array}{c}\text { Unstandardized } \\
\text { Residual }\end{array}$ \\
\hline $\mathrm{N}$ & 70 \\
Kolmogorov-Smirnov $Z$ & 1,214 \\
Asymp.Sig.(2-tailed) & 0,105
\end{tabular}

Sumber: Data statistik diolah, 2016

Berdasarkan Tabel 9, dapat dilihat bahwa nilai Kolmogorov Sminarnov (K-S) sebesar 1,214, sedangkan nilai Asymp. Sig. (2-tailed) sebesar 0,105 . Hasil tersebut mengindikasikan bahwa model persamaan regresi tersebut berdistribusi normal karena nilai Asymp. Sig. (2-tailed) 0,105lebih besar dari nilai alpha 0,05 .

Berdasarkan Tabel 10, dapat dilihat bahwa nilai Kolmogorov Sminarnov (K-S) sebesar 1,462, sedangkan nilai Asymp. Sig. (2-tailed) sebesar 0,078 . Hasil tersebut mengindikasikan bahwa model persamaan regresi tersebut berdistribusi normal karena nilai Asymp. Sig. (2-tailed) 0,078 lebih besar dari nilai alpha 0,05 . 
Tabel 10. Hasil Uji Normalitas Struktur 3

\begin{tabular}{cc}
\hline & $\begin{array}{c}\text { Unstandardized } \\
\text { Residual }\end{array}$ \\
\hline $\mathrm{N}$ & 70 \\
Kolmogorov-Smirnov $Z$ & 1,462 \\
Asymp.Sig.(2-tailed) & 0,078 \\
\hline
\end{tabular}

Sumber: Data statistik diolah, 2016
Uji heteroskedastisitas bertujuan untuk mengetahui apakah dalam model regresi terjadi ketidaksamaan varian dari residual satu pengamatan ke pengamatam lain yang dilakukan dengan uji Glejser. Jika tidak ada satu pun variabel bebas yang berpengaruh signifikan terhadap nilai absolute residual atau nilai signifikansinya diatas 0,05 maka tidak mengandung gejala heteroskedastisitas.

Tabel 11. Hasil Uji Heteroskedastisitas Struktur 1

\begin{tabular}{lrrrrrr}
\hline \multirow{2}{*}{ Model } & \multicolumn{5}{c}{ Standardized } \\
& \multicolumn{1}{c}{ Unstandardized Coefficients } & Coefficients & & \\
\cline { 2 - 5 } & \multicolumn{1}{c}{ Std. Error } & Beta & \multicolumn{1}{c}{$t$} & \multicolumn{1}{c}{ Sig. } \\
\hline (Constant) & .142 & .549 & & .259 & .796 \\
Job Involvement & .119 & .048 & .335 & 2.470 & .616 \\
Keadilan Organisasional & -.037 & .033 & -.154 & -1.137 & .260 \\
\hline
\end{tabular}

Sumber: Data statistik diolah, 2016

Pada Tabel 11, dapat dilihat bahwa nilai Sig. dari variabel Job Involvement, dan Keadilan Organisasional terhadap komitmen afektif masingmasing sebesar 0,616 dan 0,260. Nilai tersebut lebih besar dari 0,05 yang berarti tidak terdapat pengaruh antara variabel bebas terhadap absolute residual. Dengan demikian, model yang dibuat tidak mengandung gejala heteroskedastisitas.

Tabel 12. Hasil Uji Heteroskedastisitas Struktur 2

\begin{tabular}{lcccccc}
\hline \multirow{2}{*}{ Model } & \multicolumn{5}{c}{ Standardized } \\
& \multicolumn{1}{c}{ Unstandardized Coefficients } & Coefficients & & \\
\cline { 2 - 5 } & $\mathrm{B}$ & Std. Error & Beta & $\mathrm{t}$ & Sig. \\
\hline (Constant) & .169 & .499 & & .339 & .736 \\
Job Involvement & .096 & .044 & .300 & 2.198 & .631 \\
Keadilan Organisasional & -.023 & .030 & -.107 & -.784 & .436 \\
\hline Sumber: Data statistik diolah, 2016 & & & & &
\end{tabular}

Pada Tabel 12, dapat dilihat bahwa nilai Sig. dari variabel Job Involvement, danKeadilan Organisasional terhadap komitmen kontinuan masing-masing sebesar 0,631 dan 0,436. Nilai tersebut lebih besar dari 0,05 yang berarti tidak terdapat pengaruh antara variabel bebas terhadap absolute residual. Dengan demikian, model yang dibuat tidak mengandung gejala heteroskedastisitas.

Pada Tabel 13, dapat dilihat bahwa nilai Sig. dari variabel Job Involvement, dan Keadilan Organisasional terhadap komitmen normatif masingmasing sebesar 0,640 dan 0,604. Nilai tersebut lebih besar dari 0,05 yang berarti tidak terdapat pengaruh antara variabel bebas terhadap absolute residual. Dengan demikian, model yang dibuat tidak mengandung gejala heteroskedastisitas.

Uji Multikolinieritasbertujuan untuk menguji apakah pada model regresi ditemukan adanya korelasi antar variabel bebas. Adanya multikolinieritas dapat dilihat dari nilai tolerance atau variance inflation factor (VIF). Jika nilai telorance lebih $10 \%$ atau VIF kurang dari 10, maka dikatakan tidak ada multikolinieritas.

Tabel 13. Hasil Uji Heteroskedastisitas Struktur 3

\begin{tabular}{|c|c|c|c|c|c|}
\hline \multirow[t]{2}{*}{ Model } & \multicolumn{2}{|c|}{$\begin{array}{c}\text { Unstandardized } \\
\text { Coefficients }\end{array}$} & \multirow{2}{*}{$\begin{array}{c}\begin{array}{c}\text { Standardized } \\
\text { Coefficients }\end{array} \\
\text { Beta }\end{array}$} & \multirow[b]{2}{*}{$t$} & \multirow[b]{2}{*}{ Sig. } \\
\hline & $B$ & Std. Error & & & \\
\hline$($ Constant $)$ & 1.056 & .427 & & 2.471 & .016 \\
\hline Job Involvement & .079 & .037 & .278 & 2.098 & .640 \\
\hline Keadilan Organisasional & -.076 & .025 & -.399 & -3.013 & .604 \\
\hline
\end{tabular}

Sumber: Data statistik diolah, 2016 
Tabel 14. Hasil Uji Multikoleniaritas

\begin{tabular}{ccc}
\hline Variabel & Tolerance & VIF \\
\hline Job Involvement $\left(\mathrm{X}_{1}\right)$ & 0,744 & 1,344 \\
Keadilan Organisasional $\left(\mathrm{X}_{2}\right)$ & 0,744 & 1,344 \\
\hline Sumber: Data statistik diolah, 2016 & &
\end{tabular}

Sumber: Data statistik diolah, 2016

Berdasarkan Tabel 14, dapat dilihat bahwa nilai tolerance dan VIF dari variabel job involvement dan keadilan organisasional terhadap komitmen afektif, komitmen kontinuan dan komitmen normatif menunjukkan bahwa nilai tolerance untuk setiap variabel lebih besar dari $10 \%$ dan nilai VIF lebih kecil dari 10 yang berarti model persamaan regresi bebas dari multikolinearitas.

\section{Analisis Regresi Linear Berganda}

Analisis regresi linear berganda dilakukan untuk mengetahui hubungan antar lebih dari dua variabel. Hasil uji regresi linier berganda ditunjukkan pada Tabel 17.

Tabel 15. Uji Regresi Linier Berganda Struktur 1

\begin{tabular}{|c|c|c|c|c|c|c|}
\hline & \multirow[t]{2}{*}{ Model } & \multicolumn{2}{|c|}{$\begin{array}{c}\text { Unstandardized } \\
\text { Coefficients } \\
\end{array}$} & \multirow{2}{*}{$\begin{array}{c}\text { Standardized } \\
\text { Coefficients } \\
\text { Beta } \\
\end{array}$} & \multirow[b]{2}{*}{$t$} & \multirow[b]{2}{*}{ Sig. } \\
\hline & & B & Std. Error & & & \\
\hline \multirow[t]{6}{*}{1} & (Constant) & .709 & .813 & & .872 & .386 \\
\hline & Job Involvement & .144 & .071 & .177 & 2.020 & .047 \\
\hline & Keadilan Organisasional & .374 & .048 & .681 & 7.776 & .000 \\
\hline & $\mathrm{R}_{1}$ Square & & & & & 0,617 \\
\hline & F Statistik & & & & & 54,072 \\
\hline & Signifikansi & & & & & 0,000 \\
\hline
\end{tabular}

Sumber: Data statistik diolah, 2016

Berdasarkan hasil analisis regresi linier berganda seperti yang disajikan pada Tabel 15, maka persamaan strukturalnya adalah sebagai berikut:

$$
\begin{aligned}
& \mathrm{Y}_{1}=\mathrm{Bo}+\mathrm{B}_{1} \mathrm{X}_{1}+\mathrm{B}_{2} \mathrm{X}_{2}+\mathrm{e} \\
& \mathrm{Y}=0,709+0,144 \mathrm{X} 1+0,374 \mathrm{X} 2
\end{aligned}
$$

Berdasarkan hasil analisis regresi linier berganda seperti yang disajikan pada Tabel 16 , maka persamaan strukturalnya adalah sebagai berikut :

$$
\begin{aligned}
& \mathrm{Y}_{2}=\mathrm{Bo}+\mathrm{B}_{1} \mathrm{X}_{1}+\mathrm{B}_{2} \mathrm{X}_{2}+\mathrm{e} \\
& \mathrm{Y}=-0,559+0,386 \mathrm{X} 1+0,246 \mathrm{X} 2
\end{aligned}
$$

\begin{tabular}{|c|c|c|c|c|c|c|}
\hline & \multirow[t]{2}{*}{ Model } & \multicolumn{2}{|c|}{$\begin{array}{c}\text { Unstandardized } \\
\text { Coefficients } \\
\end{array}$} & \multirow{2}{*}{$\begin{array}{c}\text { Standardized } \\
\text { Coefficients }\end{array}$} & \multirow[b]{2}{*}{$\mathrm{t}$} & \multirow[b]{2}{*}{ Sig. } \\
\hline & & $B$ & Std. Error & & & \\
\hline \multirow[t]{6}{*}{1} & (Constant) & -.559 & .762 & & -.734 & .466 \\
\hline & Job Involvement & .386 & .067 & .481 & 5.784 & .000 \\
\hline & Keadilan Organisasional & .246 & .045 & .452 & 5.437 & .000 \\
\hline & $\mathrm{R}_{2}$ Square & & & & & 0,655 \\
\hline & F Statistik & & & & & 63,736 \\
\hline & Signifikansi & & & & & 0,000 \\
\hline
\end{tabular}

Tabel 16. Uji Regresi Linier Berganda Struktur 2

Sumber: Data statistik diolah, 2016 
Tabel 17. Uji Regresi Linier Berganda Struktur 3

\begin{tabular}{|c|c|c|c|c|c|c|}
\hline & \multirow[t]{2}{*}{ Model } & \multicolumn{2}{|c|}{$\begin{array}{c}\text { Unstandardized } \\
\text { Coefficients } \\
\end{array}$} & \multirow{2}{*}{ 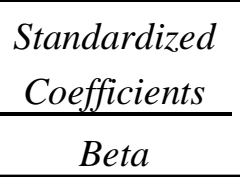 } & \multirow[b]{2}{*}{$\mathrm{t}$} & \multirow[b]{2}{*}{ Sig. } \\
\hline & & $B$ & Std. Error & & & \\
\hline \multirow[t]{6}{*}{1} & (Constant) & .888 & .658 & & 1.351 & .181 \\
\hline & Job Involvement & .423 & .058 & .583 & 7.345 & .000 \\
\hline & Keadilan Organisasional & .178 & .039 & .363 & 4.568 & .000 \\
\hline & $\mathrm{R}_{3}$ Square & & & & & 0,686 \\
\hline & F Statistik & & & & & 73,110 \\
\hline & Signifikansi & & & & & 0,000 \\
\hline
\end{tabular}

Sumber: Data statistik diolah, 2016

Berdasarkan hasil analisis regresi linier berganda seperti yang disajikan pada Tabel 17, maka persamaan strukturalnya adalah sebagai berikut :

$$
\begin{aligned}
& \mathrm{Y}_{3}=\mathrm{Bo}+\mathrm{B}_{1} \mathrm{X}_{1}+\mathrm{B}_{2} \mathrm{X}_{2}+\mathrm{e} \\
& \mathrm{Y}=0,888+0,423 \mathrm{X} 1+0,178 \mathrm{X} 2
\end{aligned}
$$

Nilai determinasi total persamaan regresi pada struktur $1\left(\mathrm{R}_{1}^{2}\right)$ sebesar 0,617 mempunyai arti bahwa sebesar $61,7 \%$ variasi komitmen afektifdipengaruhi oleh variasi job involvement dan keadilan organisasional, sedangkan sisanya sebesar 38,3\% dijelaskan oleh faktor lain yang tidak dimasukkan ke dalam model.

Nilai determinasi total persamaan regresi pada struktur $2\left(\mathrm{R}_{2}{ }^{2}\right)$ sebesar 0,655 mempunyai arti bahwa sebesar $65,5 \%$ variasi komitmen kontinuan dipengaruhi oleh variasi job involvement dan keadilan organisasional, sedangkan sisanya sebesar $34,5 \%$ dijelaskan oleh faktor lain yang tidak dimasukkan ke dalam model.

Nilai determinasi total persamaan regresi pada struktur $3\left(\mathrm{R}_{3}^{2}\right)$ sebesar 0,686 mempunyai arti bahwa sebesar $68,6 \%$ variasi komitmen normatif dipengaruhi oleh variasi job involvement dan keadilan organisasional, sedangkan sisanya sebesar $31,4 \%$ dijelaskan oleh faktor lain yang tidak dimasukkan ke dalam model.

\section{Uji Kelayakan Model (Uji F)}

Uji keterandalan model atau uji kelayakan model disebut sebagai uji F merupakan tahapan awal mengidentifikasi model regresi yang diestimasi layak atau tidak. Nilai yang tertera digunakan untuk uji kelayanan Model Analisis (dimana sejumlah variabel $\mathrm{x}$ mempengaruhi variabel $\mathrm{y}$ ) dengan ketentuan angka probabilitas yang baik untuk digunakan sebagai model regresi harus $<0,05$. Nilai ini bisa dilihat pada kolom Sig. Jika Sig. < 0,05, maka Model Analisis dianggap layak. Jika Sig. > 0,05, maka Model Analisis dianggap tidak layak.

Tabel 18 hasil uji anova (UJIF) di atas, diperoleh $\mathrm{dk}$ antar kelompok (pembanding) $=2$, dk dalam kelompok (penyebut) $=67$, pada alfa $=0.05$ maka nilai $\mathrm{F}$ tabelnya adalah $\mathrm{F} 0,05(2,67)=3,13$. Sedang $F$ hitung $=54,072$. Nilai Fhitung $>$ Ftabel, 54,072 > 3,13 , dengan nilai sig. $0,000<0,05$. Maka $\mathrm{H} 0$ ditolak pada taraf nyata 0,05 (H1 diterima). Kesimpulannya, pada kelompok yang diuji memiliki perbedaan yang nyata (signifikan).

Tabel 18. Hasil Uji Anova Struktur 1

\begin{tabular}{llrrrrr}
\hline \multicolumn{1}{l}{ Model } & \multicolumn{1}{c}{$\begin{array}{c}\text { Sum of } \\
\text { Squares }\end{array}$} & df & Mean Square & \multicolumn{1}{c}{ F } & \multicolumn{1}{c}{ Sig. } \\
\hline 1 & Regression & 213.166 & 2 & 106.583 & 54.072 & $.000^{\mathrm{a}}$ \\
& Residual & 132.067 & 67 & 1.971 & & \\
& Total & 345.233 & 69 & & & \\
\hline
\end{tabular}

Sumber: Data statistik diolah, 2016 
Tabel 19. Hasil Uji Anova Struktur 2

\begin{tabular}{llrrrrr}
\hline \multicolumn{1}{l}{ Model } & \multicolumn{1}{c}{ Sum of } & & & & & \\
& & Squares & df & Mean Square & \multicolumn{1}{c}{ F } & \multicolumn{1}{c}{ Sig. } \\
\hline 1 & Regression & 221.035 & 2 & 110.518 & 63.736 & $.000^{\mathrm{a}}$ \\
& Residual & 116.177 & 67 & 1.734 & & \\
& Total & 337.212 & 69 & & & \\
\hline
\end{tabular}

Sumber: Data statistik diolah, 2016

Tabel 19 hasil uji anova (UJI F) di atas, diperoleh $\mathrm{dk}$ antar kelompok (pembanding) $=2 \mathrm{dk}$ dalam kelompok (penyebut) $=67$, pada alfa $=0.05$ maka nilai $\mathrm{F}$ tabelnya adalah F0,05 $(2,67)=3,13$. Sedang $\mathrm{F}$ hitung $=63,736$. Nilai Fhitung $>$ Ftabel,
$63,736>3,13$, dengan nilai sig. $0,000<0,05$. Maka H0 ditolak pada taraf nyata 0,05 (H1 diterima). Simpulannya, pada kelompok yang diuji memiliki perbedaan yang nyata (signifikan).

Tabel 20. Hasil Uji Anova Struktur 3

\begin{tabular}{|c|c|c|c|c|c|c|}
\hline & Model & Sum of Squares & df & Mean Square & $\mathrm{F}$ & Sig. \\
\hline \multirow[t]{3}{*}{1} & Regression & 188.933 & 2 & 94.466 & 73.110 & $.000^{\mathrm{a}}$ \\
\hline & Residual & 86.572 & 67 & 1.292 & & \\
\hline & Total & 275.505 & 69 & & & \\
\hline
\end{tabular}

Sumber: Data statistik diolah, 2016

Tabel 20 menunjukkan hasil uji anova (UJI F), diperoleh $\mathrm{dk}$ antar kelompok (pembanding) $=2 \mathrm{dk}$ dalam kelompok (penyebut) $=67$, pada alfa $=0.05$ maka nilai $\mathrm{F}$ tabelnya adalah $\mathrm{F} 0,05(2,67)=3,13$. Sedang $F$ hitung $=73,110$. Nilai Fhitung $>$ Ftabel, $73,110>3,13$, dengan nilai sig. $0,000<0,05$. Maka H0 ditolak pada taraf nyata 0,05 (H1 diterima). Kesimpulannya, pada kelompok yang diuji memiliki perbedaan yang nyata (signifikan).

Uji Hipotesis (Uji t)

Berdasarkan hasil analisis pengaruh job involvement terhadap komitmen afektif diperoleh nilai Sig. t sebesar 0,047 dengan nilai koefisien beta 0,177 . Nilai Sig. t $0,047<0,05$. Hasil ini mempunyai arti bahwa job involvement berpengaruh positif dan signifikan terhadap komitmen afektif. Berdasarkan hasil analisis pengaruh Job Involvement terhadap Komitmen Kontinuan diperoleh nilai Sig. t sebesar 0,000 dengan nilai koefisien beta 0,481 . Nilai Sig. $t$ $0,000<0,05$. Hasil ini mempunyai arti bahwa $J o b$ Involvement berpengaruh positif dan signifikan terhadapKomitmen Kontinuan.

Berdasarkan hasil analisis pengaruh job involvement terhadap komitmen normatif diperoleh nilai Sig. t sebesar 0,000 dengan nilai koefisien beta 0,583 . Nilai Sig. t $0,000<0,05$. Hasil ini mempunyai arti bahwa job involvement berpengaruh positif dan signifikan terhadap komitmen normatif. Berdasarkan hasil analisis pengaruh keadilan organisasional terhadap komitmen afektif diperoleh nilai Sig. $\mathrm{t}$ sebesar 0,000 dengan nilai koefisien beta 0,681 . Nilai Sig.t $0,000<0,05$. Hasil ini mempunyai arti bahwa keadilan organisasional berpengaruh positif dan signifikan terhadap komitmen afektif.

Berdasarkan hasil analisis pengaruh keadilan organisasional terhadap komitmen kontinuan diperoleh nilai Sig. $\mathrm{t}$ sebesar 0,000 dengan nilai koefisien beta 0,452 . Nilai Sig. t $0,000<0,05$. Hasil ini mempunyai arti bahwa keadilan organisasional berpengaruh positif dan signifikan terhadap komitmen kontinuan.

Berdasarkan hasil analisis pengaruh Keadilan Organisasional terhadap Komitmen Normatif diperoleh nilai Sig. $\mathrm{t}$ sebesar 0,000 dengan nilai koefisien beta 0,363 . Nilai Sig. t $0,000<0,05$. Hasil ini mempunyai arti bahwa Keadilan Organisasional berpengaruh positif dan signifikan terhadap Komitmen Normatif.

\section{Pembahasan Hasil Penelitian}

Berdasakan hasil pengujian hipotesis variabel job involvement terhadap komitmen afektif diperoleh bahwa job involvement berpengaruh positif dan signifikan terhadap komitmen afektif. Hasil pengujian hipotesis job involvement terhadap komitmen kontinuan diperoleh bahwa job involvement berpengaruh positif dan signifikan terhadap komitmen kontinuan. Hasil pengujian tentang pengaruh job involvement terhadap 
komitmen normatif diperoleh bahwa job involvement berpengaruh positif dan signifikan terhadap komitmen normatif.

Job involvement secara dominan berpengaruh positif terhadap komitmen normatif karena karyawan yang ikut berperan penuh dengan pekerjaannya, mereka akan mengikuti aturan yang telah disepakati antara perusahaan dengan karyawan mengenai detail dari pekerjaan yang diberikan kepada karyawan. Secara keseluruhan job involvement berpengaruh positif terhadap komitmen organisasional, karena berdasarkan pengujian hipotesis job involvement terhadap masing masing dimensi dari komitmen organisasional (komitmen afektif, komitmen kontinuan dan komitmen normatif) menghasilkan pengaruh positif. Sejalan dengan penelitian Chin (2012) menunjukkan adanya kontribusi secara signifikan antara job involvement terhadap komitmen organisasi. Penelitian Logahan (2014) menghasilkan job involvement (keterlibatan kerja) memiliki pengaruh yang signifikan dan positif terhadap komitmen organisasi. Penelitian Khan (2011) memperoleh hasil yang signifikan antara job involvement dengan komitmen organisasi. Terbukti bahwa job involvement berhubungan positif dengan komitmen afektif, komitmen kontinuan, dan komitmen normatif yang berlokasi di Pakistan. Penelitian Uygur (2009) juga memperoleh hasil yang signifikan positif antara job involvement dengan komitmen organisasional. Penelitian Chungtai (2008) menguatkan bahwa keterlibatan kerja akan meningkatkan komitmen organisasional diantara karyawan, karyawan yang berkomitmen akan memberikan usaha yang lebih lagi sebagai perwakilan dari organisasi, yang selanjutnya secara konsekuen akan membawa kepada level yang lebih tinggi lagi dari pekerjaannya.

Hasil pengujian hipotesis variabel keadilan organisasional terhadap komitmen afektif diperoleh bahwa keadilan organisasional berpengaruh positif dan signifikan terhadapkomitmen afektif. Hasil pengujian hipotesis variabel keadilan organisasional terhadap komitmen kontinuan diperoleh bahwa keadilan organisasional berpengaruh positif dan signifikan terhadapkomitmen kontinuan. Hasil pengujian hipotesis variabel keadilan organisasional terhadap komitmen normatif diperoleh bahwa keadilan organisasional berpengaruh positif dan signifikan terhadap komitmen normatif.

Keadilan organisasional dominan berpengaruh positif terhadap komitmen afektif karena karyawan yang diperlakukan secara adil dalam perusahaannya akan memiliki pemikiran (secara emosional) bahwa ia akan lebih lama bertahan di dalam perusahaan dan suka rela mengerjakan pekerjaannya. Secara keseluruhan keadilan organisasional berpengaruh positif terhadap komitmen organisasional. Hal tersebut sejalan dengan penelitian yang dilakukan oleh Dehkordi et al. (2013) menemukan bahwa keadilan organisasi berpengaruh positif dan signifikan terhadap komitmen organisasi, kurangnya keadilan dalam organisasi akan menciptakan komitmen organisasi yang rendah. Penelitian Kristanto (2015) memperoleh hasil bahwa keadilan organisasional berpengaruh positif terhadap komitmen organisasional. Adanya perlakuan yang adil pada setiap karyawan dianggap karyawan dapat menciptakan situasi kerja yang baik, sehingga karyawan merasa betah bekerja di perusahaan. Bakhshi (2009) dengan hasil analisis regresi dari data menunjukkan bahwa keadilan distributif dan keadilan prosedural ditemukan secara signifikan berhubungan dengan komitmen organisasi. Leow (2009) dalam penelitiannya menghasilkan bahwa keadilan organisasional berpengaruh positif terhadap komitmen organisasional.

\section{SIMPULAN DAN SARAN}

Bedasarkan hasil pembahasan diatas dapat ditarik beberapa simpulan sebagai berikut: Pertama, Job involvement berpengaruh positif terhadap komitmen afektif. Ini berarti karyawan yang memiliki job involvement yang tinggi di tempat ia bekerja akan memiliki tingkat komitmen afektif (keterikatan secara emosional) yang tinggi dan apabila karyawan memiliki job involvement yang rendah di tempat kerja akan memiliki tingkat komitmen afektif (keterikatan secara emosional) yang rendah, kedua, Job involvement berpengaruh positif terhadap komitmen kontinuan. Ini berarti karyawan yang memiliki job involvement yang tinggi di tempat ia bekerja akan memiliki tingkat komitmen kontinuan (kebutuhan untuk berada dalam perusahaan) yang tinggi dan apabila karyawan yang memiliki job involvement yang rendah di tempat ia bekerja akan memiliki tingkat komitmen kontinuan (kebutuhan untuk berada dalam perusahaan) yang rendah, ketiga, Job involvement berpengaruh positif terhadap komitmen normatif. Ini berarti karyawan yang memiliki job involvement yang tinggi di tempat ia bekerja akan memiliki tingkat komitmen normatif (kewajiban untuk berada di dalam perusahaan, sesuai dengan aturan) yang tinggi dan apabila , karyawan yang memiliki job involvement yang rendah di tempat ia bekerja akan memiliki tingkat komitmen normatif (kewajiban untuk berada di dalam perusahaan, sesuai dengan aturan) yang rendah. 
Keempat, keadilan organisasional berpengaruh positif terhadap komitmen afektif. Ini berarti karyawan yang tingkat keadilan organisasionalnya tinggi di tempat ia bekerja akan memiliki tingkat komitmen afektif (keterikatan secara emosional) yang tinggi dan apabila karyawan yang tingkat keadilan organisasionalnya rendah di tempat ia bekerja akan memiliki tingkat komitmen afektif (keterikatan secara emosional) yang rendah. Kelima, keadilan organisasional berpengaruh positif terhadap komitmen kontinuan. Ini berarti karyawan yang memiliki keadilan organisasional yang tinggi di tempat ia bekerja akan memiliki tingkat komitmen kontinuan (kebutuhan untuk berada dalam perusahaan) yang tinggi dan apabila karyawan yang memiliki keadilan organisasional yang rendah di tempat ia bekerja akan memiliki tingkat komitmen kontinuan (kebutuhan untuk berada dalam perusahaan) yang rendah. Keenam, keadilan organisasional berpengaruh positif terhadap komitmen normatif. Ini berarti karyawan yang memiliki keadilan organisasional yang tinggi di tempat ia bekerja akan memiliki tingkat komitmen normatif (kewajiban untuk berada di dalam perusahaan, sesuai dengan aturan) yang tinggi dan apabila karyawan yang memiliki keadilan organisasional yang rendah di tempat ia bekerja akan memiliki tingkat komitmen normatif (kewajiban untuk berada di dalam perusahaan, sesuai dengan aturan) yang rendah.

Berdasarkan simpulan tersebut, maka saran yang dapat disampaikan adalah sebagai berikut: pertama, Pacto - Bali dapat lebih terbuka dalam menyampaikan spesifikasi pekerjaan kepada karyawan sehingga karyawan dapat merespon pekerjaan sesuai dengan yang diharapkan oleh perusahaan. Kedua, Pacto - Bali diharapkan dapat memberikan kepercayaan kepada karyawannya bahwa karyawan mampu untuk menyelesaikan pekerjaannya sesuai dengan target yang diberikan perusahaan.

Ketiga, Pacto-Bali diharapkan dapat adil dalam menetapkan prosedur kerja bagi karyawannya. Keempat, Pemimpin Pacto - Bali harus dapat menciptakan lingkungan kerja yang nyaman dan memberikan timbal balik yang sesuai bagi karyawan yang melampaui target lebih cepat dari yang ditentukan perusahaan sehingga karyawan merasa bahagia untuk menghabiskan karir di perusahaan. Kelima, Pacto - Bali dapat menerima keluhan dari karyawan dan dapat mengatasinya sehingga karyawan lebih merasa dihargai dan memiliki sedikit pilihan untuk keluar dari perusahaan.Keenam,
Pemimpin Pacto - Bali dengan karyawan diharapkan dapat memupuk sikap kekeluargaan sehingga merasa sama - sama saling membutuhkan dan saling membantu untuk pencapaian bersama tujuan perusahaan.

\section{REFERENSI}

Adekola, B. 2012. The impact of organizational commitment on job satisfaction: a study of employees at Nigerian Universities. International Journal of Human Resource Studies, Vol. 2. No. 2. pp. 1-17.

Adiapsari, R. 2012. Analisis Pengaruh Iklim Organisasi Terhadap Komitmen Dengan Kepuasan Kerja Sebagai Variable Mediasi pada Karyawan PT Tiga Serangkai Solo. Riset Manajemen dan Akuntansi, Vol. 3, No. 5, pp: 75-102.

Azeem, S. M. 2010. Job satisfaction and Organizational Commitment among Employees in the Sultane of Oman. Psychology, Vol. 1 : pp. 295-299.

Bakhsi, A., Kuldeep K., dan Ekta R. 2009. Organizational justice Perception as Predictor of Job Satisfaction and Oagnization Commitmen. International Journal of Business and Management, Vol.4, No.9.

Chin, C. H., Brian O., Gary D., dan Jing S. 2012. Work Value, Job Involvement and Organization Commitment in Taiwanese Nurses. International Journal of Psychology and Behavioral Sciences, Vol. 2, No. 3, pp : $64-70$.

Chughtai, A. A. 2008. Impact of Job involvement on In-Role performance and Organizational Citizenship Behaviour. Journal Institute of Behavioral and Applied Management, Vol. 9, No. 2, pp : 169-183.

Dehkordi, F. R., Sardar M., dan Mozafar Y. 2013. Relationship of organizational justice and organizational commitment of the staff in General Directorate of Youth and Sports in Chahar Mahal Va Bakhtiari Province. European Journal of Experimental Biology, Vol. 3. No. 3. pp. 696-700.

Faslah, R. 2010. Hubungan antara Keterlibatan Kerja dengan Turn Over Intention pada Karyawan PT. Garda Trimitra Utama. Jakarta. Economics Sains, Vol. 8, No. 2, pp : 146 - 151.

Gibson, J., John M. I., dan James H. D. 1995. Organisasi: Perilaku, Struktur, Proses. Edisi kelima Jakarta : Erlangga.

Govender, S dan SB Parumasur. 2010. The Relationship between Motivation and Job 
Involvement. SAJEMS NS, Vol. 13, No. 3, pp : $237-253$.

Hermawan, F. 2012. Pengaruh Job Enrichment Terhadap Kepuasan Kerja, Motivasi dan Komitmen Organisasi PT Fajar Surya Wisesa. Bina Ekonomi Majalah Ilmiah Fakultas Ekonomi Unpar, Vol. 16, No. 2, pp : 93-104.

Hidayah, S. dan Haryani. 2013. Pengaruh Keadilan Distributif dan Keadilan Prosedural Terhadap Kinerja Karyawan BMT Hudatama Semarang. Jurnal Ekonomi Manajemen Akuntansi, Vol. 20, No. 35, pp : 1-15.

Ibrahim, M. E. dan Ann O. P. 2014. Effects of organizational justice, employee satisfaction, and gender on employees' commitment: evidence from the UAE. International Journal of Business and Management, Vol. 9 No. 2. pp. 45-59.

Karim, F., dan Omar R. 2012.Impact of Job Satisfaction, Perceived Organizational Justice and Employee Empowerment on Organizational Commitment in Semi-Government Organizations of Pakistan. Journal of Business Studies Quarterly, Vol. 3, No. 4, pp. 92-104.

Khan, T. I., Farooq A J., Aisha M. B. K., and Syed T. H. 2010. Job Involvement as Predictor of Employee Commitment : Evidence from Pakistan. International Journal of Business and Management, Vol. 6, No. 4, pp : 252-262.

Kristanto, H. 2015. Keadilan Organisasional, Komitmen Organisasional dan Kinerja Karyawan. JMBK, Vol. 17, No. 1, pp : 86-98.

Leow, K. L. dan Kok W. K.. 2009. Organizational Commitment : The Study of Organizational Justice and Leader Member Exchange (LMX) Among Auditors in Malaysia. International Journal of Business and Information, Vol. 4, No. 2, pp : 161-198.

Logahan, J. M.., dan Sherley M. A. 2014. Budaya Organisasi dan Keterlibatan Kerja Terhadap
Komitmen Organisasi Berdampak Pada Kinerja Karyawan Pada BTN - Ciputat. Binus Business Review, Vol. 5, No. 2, pp : 551-563.

Meyer, P. J. dan Allen, J. N. 1991. A Three Component Conceptualization of Organizational Commitment. Human Resources Management Review, Vol. 1, No. 1, pp. 61-89.

Nugraheni F., dan Yulian R. W. 2009. Pengaruh Keadilan Distributif dan Keadilan Prosedural Terhadap Kinerja: Studi Kasus Pada Akademisi Universitas Muria Kudus. Academy of Management Journal, pp:1-13.

Pacto. 2011. About Pacto Company. http://www. pactoltd.com/, diakses 15 Januari 2016.

Robbins, S.P. 2003. Perilaku Organisasi. Jakarta: PT. Index Group Gramedia.

Robbins, S. P. dan Timothy, A. J. 2008. Perilaku Organisasi. Edisi 12. Terjemahan oleh Diana Angelica, Ria Cahyani, Abdul Rosyid. 2008. Jakarta : Salemba Empat.

Sutrisna, I W. W. dan Agoes G. R. 2014. Pengaruh Keadilan Distributif, Prosedural, dan Interaksional Terhadap Kepuasan Kerja dan Komitmen Organisasi Pada Paramedis di Rumah Sakit Tk II Udayana Denpasar. EJurnal Manajemen Universitas Udayana, Vol. 3, No. 9, pp : 2489 - 2509.

Uygur, A., dan Gonca K. 2009. A Study into Organizational Commitment and Job Involvement : An Application Towards the Personel in the Central Organization for Ministry of Health in Turkey. Ozean Journal of Sciences, Vol. 2, No. 1, pp :113 - 125.

Yavuz, M. 2010. The Effect of Teacher's Perception of Organizational Justice and Culture on Organizational Commitment. African Journal of Business Management, Vol. 4, No. 5, pp : 695-7 